\title{
Europe 'needs one voice on large machines'
}

London. France is planning to propose that European research ministers should hold an annual meeting to establish a joint position in negotiations with the United States and Japan on the financing, construction and use of future large-scale research facilities.

It is also suggesting, as the current president of the Council of Ministers, that the political status of the European Commission's Science and Technology Research Committee (CREST) should be raised, taking it out of the hands of the commission and turning it into an advisory committee to the council itself.

Both moves are intended to reinforce efforts at establishing a European-level policy for science, but without giving excessive powers to commission officials in Brussels and thus acknowledging the need to respect the concept of 'subsidiarity'. But both are also likely to be closely examined by other member states of the European Union (EU) to see whether changes being proposed by France will have a significant practical impact.

Speaking at a meeting in London last week, François Fillon, the French minister for research and higher education, said that Europe's recent decision to proceed with the construction of the Large Hadron Collider (LHC) at the European Laboratory for Particle Physics (CERN) - inviting Japan and US participation as being desirable but not essential - indicated the strength of taking a joint approach (see Nature 372,$713 ; 1994$ ).

"The Europeans must be able to speak with one voice, when they so wish, in negotiations with Washington and Tokyo," said Fillon, delivering the annual Zuckermann lecture organized jointly by the Cabinet Office's Office of Science and Technology and the private Foundation for Science and Technology. The LHC decision, he added, had demonstrated "the resolution of the member states of CERN to more forwards, among Europeans, prior to discussions with third countries".

Facilities such as CERN and the recently created European Synchrotron Radiation Facility indicated that much had already been achieved towards creating a 'Europe of science'. But Fillon added that "much remains to be done to combine our strengths, consolidate our experience [and] launch new initiatives".

One need, he said, is to invent new institutional, financial and political forms for European scientific cooperation. "Our priority must be the scientific optimization of all projects which are necessarily undertaken by means of an agreement between European [states]," said Fillon.

Such optimization should determine the forms of cooperation, and not the reverse, he said. "Everything must be done to avoid the construction of a scientific Europe locked

into too formal an institutional approach, which creates problems rather than solving them."

When it comes to large-scale equipment that can be constructed only through global cooperation, Fillon said that Europe must be in a position to exert influence as a major player in multilateral negotiations. Ways should be found of encouraging both US and Japanese participation in European facilities without changing either their scientific or institutional objectives, as well as responding to the aspirations of the countries of Central and Eastern Europe.

Recognizing the increasing importance of large research facilities of multi-

IMAGE

\section{UNAVAILABLE} FOR COPYRIGHT REASONS

\section{Fillon: seeking a} 'rational realism'.

\section{their position in such negotiations.}

The proposed reform of CREST would help to turn the committee, which has recently been criticized for becoming increasingly bogged down in administrative responsibilities (see Nature 370, 166; 1994), into what Fillon described as a "permanent, high-level body to debate the major issues of European research".

European states "do not have a place where they can debate major issues because this is in the hands of the commission, which is responsible for the agenda of the committee," said Fillon. "We want to clarify the situation, and to see the committee being run by whichever state also holds the presidency of the EU."

Many of Fillon's ideas coincide with those of Edith Cresson, the former French prime minister who took over this week as the new EU commissioner for research. She has already indicated a desire for a greater political involvement by member states in promoting scientific initiatives at the European level (see Nature 373, 183; 1995).

At the same time, while endorsing closer collaboration on the construction of research facilities, Fillon warned that basic research should be acknowledged as a field "which cannot a priori lend itself to a transfer of skills at European Union level" - an apparent reference to the need for each country to build up and protect its own scientific community; that "France would not be able to relinquish such a crucial factor determining its future".

He also emphasized that European-level collaboration in science has to correspond to the national interests of member states, describing this approach as a "rational realism" without which the building of a "Europe of science' risks becoming engulfed in complicated bureaucratic procedures designed in Brussels.

"[Procedures for] the adoption of the community Framework research programme and the management of invitations to tender [for contracts] are already exceptionally heavy and complex," Fillon said. "If we fail to react, the very legitimacy of such a noble ambition will be compromised in the long term in the eyes of both researchers and companies."
David Dickson

\section{But France keeps EMBL guessing}

Munich. France's approach to Europeanlevel collaboration in science (see above) is already being put to the test over its attitude towards plans by the European Molecular Biology Laboratory (EMBL) to combine two independent ventures at a single site near Rome: a concentration of molecular biology research groups, and a proposed European mouse gene repository.

Italy threatened to leave EMBL last year because it did not feel that it was receiving sufficient return on its investment. The threat was withdrawn before Christmas after the Italian government had been reassured by EMBL's eagerness to give Italy a better deal - including its agreement to place four 'regional research groups' in laboratories at Monterotondo near Rome.

EMBL is hoping that these laboratories will also be selected as the site of a mouse gene repository, for which a consortium of national research organizations are seeking EU support through a special research infrastructure programme.

But two of the four countries involved in the application for funds - France and Britain - have still not agreed that Monterotondo is the best site. Both are apparently concerned that the negotiations between EMBL and Italy have appeared to pre-empt a decision without full discussion within the consortium.

Discussions are still taking place over who should apply for the EU funds - the deadline is in March - and who should take on the management of the repository. France, which opposes any expansion of EMBL on cost grounds, believes that management should be left to one or more national research organizations. A. A. 